\title{
Supply Chain Localisation as a Social and Environmental Business Value: How Applicable Is This in Practical Terms?
}

\author{
Tochukwu Onyido, David Boyd, Niraj Thuraraijah \\ Birmingham City University, Birmingham, UK
}

\begin{abstract}
This paper was written to explore the viability of supply chain localisation as a strategy for minimising possible adverse environmental and social impacts of large-scale economic activity surrounding the production of sustainable energy products. Supply chain localisation here refers to the situation of production activities close to the geographical areas in which the sustainable energy products would eventually be installed. Sustainable energy products refer to technologies and other goods and services that minimize negative environmental effects of energy use in buildings throughout their construction and habitation. The paper dwells on the operations of a major energy-efficiency programme based in the West Midlands, UK, which focused on preparing providers of sustainable energy products for the Green Deal — a UK-wide housing retrofit initiative — and the attendant increase in economic and industrial activities that the Green Deal is expected to generate. Participant observation and interviews were used to conduct a study of the programme. As part of measures to ensure that Green Deal-related activities yield minimal negative environmental and social effects while optimising economic benefits, programme participants recommended the localisation of the supply chain for the production, installation, and maintenance of sustainable energy products. The paper examines the programme outputs and focuses particularly on the concept of supply chain localisation. Based on the primary research conducted, as well as secondary research sources, the paper discusses the economic, social, and environmental benefits and detriments of the supply chain localisation agenda. It also looks at the overall practicality of the implementation of supply chain localism within the context of mainstream business practices.
\end{abstract}

Keywords: localisation, supply chain, Green Deal, sustainable energy products, United Kingdom

\section{Introduction}

Environmental concerns over negative impacts of energy generation and usage on the ecology, coupled with economic/political concerns over the volatility of fossil energy prices and unstable relationships with some crude oil-producing nations, have long since been increasing the UK government's emphasis on energy conservation, carbon emissions reduction, and a shift towards renewable energy sources (Brown, 1996). Within

Tochukwu Onyido, MSc., Faculty of Technology, Engineering, and the Environment, Birmingham School of the Built Environment, Birmingham City University.

David Boyd, Professor, Faculty of Technology, Engineering, and the Environment, Birmingham School of the Built Environment, Birmingham City University.

Niraj Thuraraijah, Ph.D., Faculty of Technology, Engineering, and the Environment, Birmingham School of the Built Environment, Birmingham City University.

Correspondence concerning this article should be addressed to Tochukwu Onyido, Birmingham School of the Built Environment, Faculty of Technology, Engineering, and the Environment, Birmingham City University, Millennium Point, Curzon Street, Birmingham, West Midlands, B4 7XG, United Kingdom. E-mail: ben.onyido@bcu.ac.uk. 


\section{SUPPLY CHAIN LOCALISATION AS A SOCIAL AND ENVIRONMENTAL BUSINESS VALUE}

the UK built environment, a recent reflection of this trend is the commencement of the Green Deal programme, a government initiative aimed at retrofitting the country's residential building stock with a range of sustainable energy products that includes insulation, window-glazing, low-energy lighting, and heating, "smart" and automated energy control systems, and renewable energy technologies such as solar photovoltaics, wind turbines, biomass boilers, and geothermal systems. In addition to its intended socio-environmental goals of fuel poverty reduction and energy conservation, the Green Deal is being actively promoted by the government as a major opportunity for the creation of new businesses and the stimulation of economic and industrial growth (DECC, 2010).

Due to their roles in reducing adverse environmental impacts of energy use, organisations that are involved in the provision of sustainable energy products for buildings which are commonly associated with the "green economy" and its attendant focus on ecosystem preservation and social development (Placet, Anderson, \& Fowler, 2005; Brand, 2012). However, previous researches suggest that the application of traditional business practices to green building initiatives could give rise to the following risks: (1) new environmental and social problems could arise in the process of solving existing ones; and (2) the sustainable energy products could fail to achieve the expected level of technical performance if not installed in the right manner (Schmidt, 2003; De Simone \& Popoff, 2000). This is mainly because traditional mainstream business practices are based largely on economic considerations, with environmental performance and social success having only secondary relevance (Isaksson, Johansson, \& Fischer, 2010). It is conceivable that a combination of the aforementioned risks could lead to a worsening of socio-environmental problems associated with the use of energy for the construction and operation of buildings, damaging investor, and consumer confidence within the still-evolving UK market, and thus discouraging further uptake of sustainable energy solutions.

Perhaps in awareness of this situation, a number of organisational networks, research institutes, and think-tank groups have planned and are planning the development of a major industry around the Green Deal which will be economically, environmentally, and socially viable all at once. One of such initiative is a major energy-efficiency programme based on the West Midlands and made up of members of several organisations from the construction, energy, housing, local/regional authority, and education sectors. The programme has so far focused on the challenge of developing the supply chain, skills, resources, and market demands ahead of the commencement of the Green Deal, and of optimizing economic, environmental, and social returns from this activity. One of the outcomes of deliberations within the programme was that the supply chain for the manufacture, installation, and maintenance of sustainable energy products for buildings should be localised. The localisation of the supply chain was presented as having the multiple functions of facilitating domestic economic growth, generating new employment, and allowing for a closer environmental monitoring of the production and delivery of sustainable energy solutions.

With all these benefits attached to it, supply chain localisation appears on the surface to be worth considering as a possible route for the sustainable energy solutions industry to expand economically whilst minimising negative environmental and social impacts. However, while the West Midlands energy-efficiency programme identified the potentials of supply chain localisation, it was less definite about the feasibility and possible adverse consequences of such a move. This paper attempts to explore the supply chain localisation route in broader detail, establishing precedence for it in environmental economics studies, evaluating the current degree of its application in the sustainable energy sector, and analysing its economic and socio-environmental implications. 
The next section of this paper touches on the nature and emergence of the supply chain localisation concept with respect to the commercial provision of sustainable energy products and services for the built environment. An overview of the methodology used by this author to investigate the energy-efficiency programme is then presented. Findings from the investigation are provided, with particular emphasis on the project's endorsement of supply chain localisation for the sustainable energy and sustainable building sectors. The practicality of supply chain localisation is then discussed, drawing on both literature sources and the primary research.

\section{A Return to Old Ways?}

Alaane and Saari (2006) presented the concept of localisation of the manufacture and distribution of energy products as one that has come round full circle. To illustrate their point, they cite even fundamental examples, such as the collection of wood and biomass for use as fuel within individual houses, as a practice that has origins dating back centuries. In this regard, localisation could be viewed as a resurgent phenomenon that is a reasonable alternative to the practice of globalisation and its attendant environmental and social detriments. However, the existing body of literature that offers an exposition on this perspective is quite limited. Practical applications of supply chain localisation to the commercial provision of sustainable energy products appear to vary depending on the nature of the energy product, technology, or service in question. Nor does there seem to be an established, quantitative definition of localisation in terms of distance or other geographical terms, e.g., how far away from its eventual point of use can a sustainable energy technology be produced before its production can no longer be described as "localised"?

In general, localisation refers to the improved utilisation of local resources in energy systems, and it could take the form of local fuel harvesting and storage, the promotion of local business opportunities, and the development of products and services based on local raw materials and labour (Alaane \& Saari, 2006). Within the renewable energy sector and indeed other economic sectors, a prevalent trend has been western firms' location of their manufacturing - and ever increasingly, research and development - infrastructure in countries like India and China (Cusmano, Mancusi, \& Morrison, 2010; Christopher, 2005). Lewis and Wiser (2007) reported that notable wind turbine manufacturers from major western markets such as USA, Germany, Denmark, and Spain first grew and developed a stable base within their home countries before eventually relocating their facilities to China, India, and other developing economies. If the home countries provided a conducive business climate for these companies to grow and stabilise to begin with, then why did the firms choose to relocate their production activities?

Within the late 20th century, a tendency grew among manufacturing and service companies to achieve greater specialisation of their functions (Kim, 1995). Outsourcing of tasks that fell outside their core competencies became a way of realising this (Humphrey, 2003; Nassimbeni, 2003). According to Perrot and Filippov (2011), within the renewable energy sector there was also the issue of high operational costs that characterise markets like wind and solar, and which make the markets depend on production incentives, local subsidies, and tax benefits. Thus, sustainable energy companies became attracted to the low-cost advantages and large market size in emerging Asian economies, the relatively adequate level of existing skills and facilities there, and the previous success of destination countries like Taiwan and China in the manufacture of semiconductors and microchips; the stagnation of western markets at intervals between the 1980s and the current decade further catalysed this trend (Perrot \& Filippov, 2011). 
All through this period of off-shoring, however, locally manufactured products retained their reputation for offering shorter lead times and higher quality assurance, and in more recent times, there appears to be an increasing interest among governments and businesses in parts of the developed world in encouraging localised production (Melani, 2006). Straka (2002) offered a political perspective on the reason behind the re-emergence of localisation in the energy sector in particular, stating that concerns over political conflicts in some of the major crude oil-producing nations and their attendant risk to supply chain security heighten the need for other countries to focus on the development of local energy options. Another common social argument against the "internationalisation" of companies' operations is that it results in the loss of jobs in the companies' home countries (Hamilton \& Summy, 2011; Alaane \& Saari, 2006; Li, 2005). However, Perrot and Filippov (2011) suggested that the transfer of functions such as research and development to overseas locations is not always a "zero-sum game", as it does not by default lead to the closure of corresponding jobs in the home country. Other reasons that are attributed towards the support for localisation include rising labour costs in developing countries, rising energy costs, the export-import balance, currency depreciation, and the leaning of public attitudes towards environmental protection and social responsibility (Longo, Markandya, \& Petrucci, 2008; Ristola \& Mirata, 2007; Walker, 1995). The Economist (2012) reported that with a 5\% per annum inflation rate in shipping costs and a wage inflation rate estimated at 30\% per annum, by 2015 it will be just as cheap to manufacture in North America for the domestic market as it would be to manufacture in China.

\section{Preparation for the Green Deal: A Project Case Study}

The Green Deal is a UK governmental policy aimed at encouraging the widespread implementation of a diverse range of sustainable energy products across the country, from insulation to window glazing to low-energy lighting and heating systems to renewable energy technologies, and it went "fully live" in January 2013 (Richards, 2013). In order to investigate how the production and installation of sustainable energy products for buildings can be expanded to become a significant UK industry through the Green Deal, while minimising possible adverse environmental and social impacts of such a large-scale economic action, this author became involved in a major energy-efficiency programme in the West Midlands. The programme has a formal goal of increasing the uptake of sustainable energy products in both new and existing buildings within the West Midlands in particular and the UK in general. It also focused on developing supply chain, skills, finance, and other resources in preparation for the Green Deal, and on optimizing the economic, environmental, and social returns from this activity. In this regard, the programme presents a situation in which the economic activities involved in the development of business capacity for a range of sustainable energy products for buildings are actively considered within social and ecological contexts.

The programme is made up of representatives of 30 organisations from the construction, energy, and property sectors. Most of the companies represented in the programme are involved in the procurement, supply, installation, and/or maintenance of sustainable energy products in buildings. The programme also includes the contribution of big utility companies such as E.on. During the programme, company representatives frequently came together in meetings, workshops, and other sessions to decide on the type and quantity of resources and skills needed to meet the market demand that was expected to be created by the Green Deal. The participants also planned how sustainable energy products would be sourced, distributed, and installed in buildings, and they worked on putting together a supply chain network for all the activities involved.

Upon gaining access to the programme, the researcher not only listened to, watched, and recorded the 
verbal and written interactions that took place among participants, but also participated in these interactions. This was in order to gain first-hand knowledge and experiences about the planning and decision-making processes involved, and also to gain the confidence of other participants and ensure that his presence would not alter how they responded to issues. This field research technique of participating in a culture or context while at the same time recording, what is being observed, is identified as participant-observation in several research literatures (Iacono, Brown, \& Holtham, 2009; Trochim, 1999; Langley, 1986). According to Iacono et al. (2009) and Trochim (1999), participant observation requires the researcher to participate in a culture or procedure while at the same time recording what is being observed. This is in contrast to complete or direct observation, which involves the researcher being unobtrusive and wholly detached (Iacono et al., 2009; Trochim, 1999). Cresswell (2012) reported that a researcher's participation in the activity being studied could influence the behaviour of the "real" participants. Thus, in order to acquire reliable data, the researcher has to gain the confidence and trust of other research participants in order to minimise the risk of them altering their "normal" behaviour (Snow \& Thomas, 2007; P. A. Adler \& P. Adler, 1987). This in turn gives rise to the risk that the researcher could be required to perform "favours" for all or part of the group (for instance, the researcher could be put under pressure to support a particular viewpoint), which could run contrary to good research practice (Yin, 2003). Yin (2003) further mentioned that the participant role may require too much attention relative to the observation role, and that the researcher may thus not be able to commit enough time and effort towards recording data or conducting deeper enquiry. Other authors such as Iacono et al. (2009), Proverbs and Gameson (2008), and Trochim (1999) raise concern over the time-consuming nature of observation in general, and the propensity for researcher bias in his/her perception of what is being observed.

To ensure that the researcher's presence in the programme would not compromise the reliability of the data obtained, the researcher's participation was limited to a relatively minor role, carrying out instructions given by complete participants, i.e., company representatives, rather than contributing an original perspective. Thus, the outputs of each session were based on the contributions of the other participants and did not reflect the researcher's own views. To establish consistency, care was taken for the researcher's role to be maintained at a constant level (without becoming more active) for the duration of the programme.

Qualitative data were collected through the recording of field notes about the specific subject of investigation, i.e., the expansion of the commercial provision of sustainable energy products for buildings into a major industry whilst minimising unintended adverse environmental and social consequences (and maximising the environmental-social benefits) of the expansion. The field note has been described severally in research literatures as a written record of what researchers have observed and learnt about what is being studied, and it involves transforming observed interaction into written communication (Pope, Ziebland, \& Mays, 2006; Jackson, 1990). The capturing of data by written means was preferred by this researcher due to its unobtrusive nature when compared with mechanical devices such as a video recorder; an audio recorder would have been similarly unobtrusive, but would not have been able to capture the non-verbal gestures and interactions that took place. The effectiveness of field notes in taking account of actions, speech, and text occurring within a dynamic situation, and thus generating more coordinated information, is supported by authors such as Saldana (2009) and Yuan (2001). However, the use of field notes is not devoid of criticism; an oft-cited one is that there is a lack of research consensus about how field notes should be written and structured (Emerson, Fretz, \& Shaw, 2011; Mulhall, 2003).

In order to optimise the reliability of the field note data, care was taken to ensure that the field notes 
exclusively contained the project participants' actions, verbal and written interactions, perspectives, plans, and decisions that related to how capacity should be developed for the production of sustainable energy products for buildings ahead of the Green Deal. Also, other important documentation created by the participants during the course of the programme - such as formal reports about the outcome of each programme task-were obtained as additional evidence.

In addition to participant observation, interviews were also conducted in order to determine the effects that a company's implementation of environmentally and socially responsible practices could have on its business capacity. Interviews are described by Holstein and Gubrium (2001) as conversations coordinated by someone (the interviewer) with the aim of obtaining information that is relevant to the research objectives. Interviewing is the most common and versatile way of collecting primary data about people's experiences by which the interviewer can probe for responses and examine issues such as motives and feelings (Kumar, 2005; Saunders, Thornhill, \& Lewis, 2006; Bell, 1993). It is not without its challenges, however, as a lot of responsibilities are placed on the researcher to negotiate an effective relationship with the interviewee in order to yield valid and detailed data that are only minimally affected by human complexities (Haigh, 2008). There is also a risk of bias on the parts of both the interviewee and the interviewer, and of inaccuracies due to poor recollection (Yin, 2003).

The interviews were semi-structured, i.e., they involved the use of pre-set but open-ended questions in order to allow for expansion on points raised by the respondents, and they also left room for additional questions to be asked when necessary (J. Gall, W. Gall, \& Borg, 2003). The semi-structured interview format was selected for use due to its relatively balanced approach, which provides more consistency than informal interviews, but still allows a greater degree of freedom and adaptability in getting information from respondents when compared to structured interviews (Haigh, 2008). In all, 20 interviews were conducted, at which point "saturation"- - new data fitting into categories already devised from old ones without introducing any new category (Charmaz, 2003) — was considered to have been achieved.

The field note and interview data were subsequently analysed through the process of coding. Coding involves conceptualising data, elaborating it in terms of its different properties, and relating the concepts that emerge (Strauss \& Corbin, 1998). In this way the data were first organised into different subsets, and then related subsets were grouped together under the same category. Information was inferred from each category and then pieced together to generate a statement of findings. The extraction of theoretical output from data in this manner is commonly described as "induction" in literature (Alvesson \& Skoldberg, 2009; Flick, 2009; Howitt \& Cramer, 2008; Fereday \& Cochrane, 2006).

\section{Research Findings}

The observation of the programme indicates that supply chain localisation is viewed as a useful measure that could be taken to ensure that the expansion of commercial provision of sustainable energy products for UK buildings does not create new environmental and social problems. Possible new environmental and social problems that could arise as a result of the expansion were identified in the programme as the following: The production of renewable energy technologies and other products could result in new emissions releases, energy losses, and waste generation across the products' supply chain; the wholesale installation of sustainable energy products could have a disruptive and invasive effect on existing housing structures, fittings, and occupants; and energy costs could be increased rather than reduced. 
While the invasive and disruptive nature of the installation of sustainable energy products in buildings appears to be temporary in scope, lasting only for the duration of the installation process, programme participants felt that it could nevertheless serve as a disincentive for building occupants to view sustainable energy products favourably. The prospect of an increase in energy costs was attributed by participants to the inability of the current electricity grid network to absorb additional power from solar photovoltaics (PV) and other micro-generation technologies. This presents a significant case of sustainable energy products creating a social effect opposite to that which was intended, i.e., the alleviation of fuel poverty. The risk of an increase in emissions, energy loss, and waste as a result of the intensification of production activity was also acknowledged by the participants, as there was the underperformance of sustainable energy products in buildings due to the inadequate integration of the products with the existing building facilities and the behaviour of building users.

In order to prevent the occurrence of these environmental and social risks, the participants endorsed the localisation of the supply chain for sustainable energy products. The programme participants shared the view that the adoption of supply chain localism for the implementation of the Green Deal has the potential to stimulate UK economic growth to a significant extent. The creation of new businesses and employment and poverty reduction opportunities in local authority areas throughout the United Kingdom was identified as a major potential benefit of supply chain localism. For instance, this researcher observed that the participants targeted the Not in Education, Employment or Training (NEET) section of local populations as a source of new members of a multi-skilled workforce for the Green Deal. Beyond the socio-economic rationale behind the participants' support for supply chain localism, there were environmental reasons as well, in terms of the need to minimise the energy, emissions, and waste issues associated with procuring, transporting, installing, and maintaining both production materials and finished sustainable energy products. The participants were of the view that the localism approach would allow for a closer monitoring of the production and delivery of sustainable energy solutions to guarantee that only minimal or zero harmful environmental impacts are yielded.

The need for sustainable energy products to be installed and maintained with minimum social disruption and optimum technical performance, as well as the NEET category's current lack of work experience, led the participants to propose the reskilling and multiskilling of current and future members of the building industry workforce. In addition, with respect to the implementation of sustainable energy products in buildings, the participants advocated an approach that focuses on the integration of different sustainable energy products within buildings (rather than on the efficiency of any single product in itself), in order to ensure that different products fully complement each other. They also proposed that building occupants and other building users should be engaged in the Green Deal preparation process in order for their perspectives to be obtained on how sustainable energy products can be installed with minimum disruption to their lives. However, the setting up of local supply chain activities and the skills training require a high level of financial investment, and so the participants focused on highlighting the economic benefits that might accrue to the companies in the future to offset the initial investment costs. The aim was to encourage companies to take a longer-term view of the business rather than seeking quick economic wins. Apart from cost, participants acknowledged that there are lingering issues concerning the disruption that a wholesale transition to localisation could cause the industry, which currently operates on a more globalised, neo-liberal market system and relies significantly on the procurement of renewable energy technologies and other major products from China and other external markets.

The interview data suggest that companies acknowledge local sourcing and procurement as a major way 
by which they can implement socio-environmental responsibility. The interviewees acknowledged the role of localisation in reducing the embodied energy of sustainable energy products (i.e., the energy consumed in the process of sourcing, producing, and distributing them), carbon emissions, and negative social impacts. As one interviewee put it:

If you are sourcing locally, you have got a little bit of comfort that... the product itself is being manufactured in the right kinds of ways. (Onyido et al., 2013, p. 8)

Another interviewee questioned:

What is the carbon emissions to bring that piece of material from China?... That could be a substandard material and it is not got the lifespan that you think it is got and then you have got to dump it anyway. (Onyido et al., 2013, p. 9)

However, environmental and social criteria were found to increase the intensiveness of materials specification and add to the overall complexity of the procurement process. Interviewees conveyed further scepticism about the cost implications of supply chain localisation. For instance, one interviewee mentions that "There is a lot of investment required for new manufacturing facilities", while another states that "The costs are more upfront as well... which is what the stumbling block, I think, is". The emphasis on localisation may also require a company to forego expansion opportunities. For example, an interviewee states:

We could have had the model of being the biggest nationwide installation company covering the whole country, but I decided ...that wasn't the best model. The better model is for there to be an installation company in every town or village or wherever ...it creates local employment. (Onyido et al., 2013, p. 11)

Local partners may not always offer the financial quotes, and this means that companies may have to forego cheaper partnership options.

\section{The Implications of Supply Chain Localisation for the Commercial Provision of Sustainable Energy Products for Buildings}

The data obtained from this author's study of the West Midlands energy-efficiency programme indicate that the localisation of the sustainable energy products' supply chains has the social benefit of creating new jobs, and it also provides extra income for building occupants through their sales of surplus electricity, which in turn serves as an incentive for the public to use energy more efficiently. Environmentally, it allows for greater monitoring of production activities to ensure that they yield only minimum adverse ecological effects, and it reduces the distance across which products can be distributed, thus reducing the release of carbon emissions in the case of fossil fuel-based transportation. Authors such as Hamilton and Summy (2011) and Ristola and Mirata (2007) support these findings. Research conducted by Holweg, Disney, Holmstrom, and Smaros (2005) suggests that the closer and less dispersed a supply chain is, the easier it is to implement synchronised production and inventory control, and the greater the returns on individual collaboration between different parties in the chain. Albino, Izzo, and Kuhtz (2002) supported this position, stating that the agglomeration of production processes in a given geographic area can improve supply chain efficiency. Fisher (1997) pointed out that for innovative products - such as sustainable energy products within the UK market —a local supply chain enhances a company's ability to maintain low levels of inventory, increase flexibility, shorten lead times, and respond quickly to customer demand trends. In this regard, investment in supply chain localisation pays for itself and offsets disadvantages such as the high cost of labour when compared to outsourcing it to cheaper 
economies (Sheffi, 2001; Fisher, 1997). According to Christopher (2005), increased supply chain responsiveness is especially crucial to volatile markets, such as that for sustainable energy products in the UK, as such an environment severely limits the accuracy of forecasts and makes it difficult for a company to make long-term plans. Rio and Burguillo (2009) mentioned that the social benefits of the localisation of renewable energy production activities extend beyond employment creation to impact on social cohesion, education, and income distribution. Localisation also acts as a disincentive for emigration, and in so doing it indirectly alleviates environmental problems that are connected with the depopulation of rural areas, such as desertification and erosion (Rio \& Burguillo, 2009).

Despite these benefits, there are wider concerns surrounding the feasibility of localisation. From an economic angle, the infrastructure required for the setting up of a completely local manufacturing base involves a high level of initial investment, which programme participants identified as a significant barrier to the development of business capacity for the implementation of supply chain localisation and other recommended measures. This viewpoint is echoed in literature as well (Omer, 2008; Sawin, 2006). Even in the case of biomass energy systems, which benefit from the local availability of feedstock, Lam, Varbanov, and Klemes (2010) stated that extensive infrastructure networks are required for harvesting, transportation, storage, and processing activities. The relatively low energy output produced per unit volume of renewable energy sources such as biomass increases the cost, emissions, and complexity of supply chains (Lam et al., 2010). Richard (2010) indicated that independent local suppliers may only be adequate for small-scale energy generation activity; a more practical alternative to regional or global market arrangements is the operation of single companies on large contiguous land areas in order to achieve a less fragmented but distributed approach. However, this system comes with problems associated with land access and appropriation, and there is also the issue of setting up contingency plans for backup suppliers (Richard, 2010).

The issue of high implementation costs is further compounded by the ambiguity that still surrounds the funding mechanism for the Green Deal, as well as by the insufficient security of market demand, which makes such a high volume of investment harder to justify (Laughlin, Davies, Dockerill, Onyido, \& Lansdell, 2012; Wustenhagen \& Bilharz, 2006). The existence of an effective capital funding programme or other policy interventions run by either the government or the private sector could encourage the strengthening of local supply chains (Crone \& Roper, 2001). Since the availability of these programmes can be affected by the wider economic climate within the country (for instance, in times of recession such funding streams could become narrower), it follows that the extent to which companies implement localisation is as much a reflection of external political and economic factors as it is of companies' internal resolve. Localisation also sets up a conflict with the mainstream business practice of globalisation, as noted by participants at the energy-efficiency programme.

The limitations of the supply chain localisation concept are not just confined to the social and economic fronts either. There is counter-evidence to the view that localisation is truly beneficial in an environmental sense as well. If global energy consumption remains unchanged and traditional fuels and technologies are still used, the volume of emissions reduced by decentralised renewable power plants in particular would remain constant rather than rise (Alaane \& Saari, 2006). In other words, the localisation of energy generation may redistribute global emissions but not reduce it. In regard to this, the intensification of local manufacturing and other production activities within the UK could cause a setback to the country's achievement of its energy and carbon emissions reduction targets (Anderson \& Fergusson, 2006; Tsoutsos, Frantzeskaki, \& Gekas, 2005). Furthermore, the potential benefits of localisation with regard to resource conservation are also liable to be 
exaggerated because assessment studies do not always fully take into account supply chain-related processes that take place outside a given location (Albino et al., 2002).

Putting the whole picture together, while supply chain localisation has significant benefits, there is also an active risk that it could well disrupt supply beyond the short-to-medium-term, have major negative economic repercussions for the industry, and jeopardise the socio-economic potentials of localisation that have been previously identified in this work, all without achieving significant positive net energy and carbon impacts.

\section{Conclusions}

This paper has focused on supply chain localisation as a potential strategy for minimising possible negative environmental and social impacts that a major expansion of the production and installation of sustainable energy products could have. It looked at existing literature on the subject and also studied a major energy-efficiency project that is working on how the Green Deal, a major UK-wide housing retrofit initiative, can deliver optimum economic, social, and environmental benefits.

Energy loss, waste generation, and emissions release as a result of the production, distribution, and eventual disposal of sustainable energy products, could increase the negative environmental effects of the products along their lifecycle. On the social front, the Green Deal could inadvertently increase energy costs for customers, and the mass installation of sustainable energy products in buildings could be disruptive and invasive to building occupants, structures, and fittings, creating a disincentive for the public to view the products favourably. To minimise the possibility of the above environmental and social risks occurring, participants at the energy-efficiency programme endorsed among other things the localisation of the supply chain for the production, installation, and maintenance of sustainable energy products. Supply chain localisation has a number of potential economic, social, and environmental benefits, such as the creation of new businesses and jobs, the creation of additional income for building occupants, and closer environmental monitoring of production activities. However, these benefits are countered by other significant factors such as its high financial investment requirements and the constraints brought about by its conflict with mainstream globalisation practices. As a result, while supply chain localisation represents a sustainable business option in principle, the scope for its application remains limited and reliant on standard policy tools such as subsidies, tax reliefs, and other regulatory measures that could significantly lower the cost of doing business in the UK. Future studies could focus on how to resolve the barriers to supply chain localisation rather than only promoting its benefits.

\section{References}

Adler, P. A., \& Adler, P. (1987). Membership roles in field research. Thousand Oaks, C.A.: Sage Publications.

Alaane, K., \& Saari, A. (2006). Distributed energy generation and sustainable development. Renewable and Sustainable Energy Reviews, 10(6), 539-558.

Albino, V., Izzo, C., \& Kuhtz, S. (2002). Input-output models for the analysis of a local/global supply chain. International Journal of Production Economics, 78(2), 119-131.

Alvesson, M., \& Skoldberg, K. (2009). Reflexive methodology: New vistas for qualitative research (2nd ed.). London, LDN: Sage Publications.

Anderson, G., \& Fergusson, M. (2006). Energy from biomass in the UK: Sources, processes and biodiversity implications. IBIS, 48(1), 180-183.

Bell, J. (1993). Doing your research project: A guide for first-time researchers in education and social science (2nd ed.). Philadelphia, PE: Open University Press. 
Brand, U. (2012). Green economy-The next oxymoron? No lessons learned from failure of implementing sustainable development. GAIA-Ecological Perspectives for Science and Society, 21(1), 28-32.

Brown, L. (1996). We can build a sustainable economy. The Futurist, 30(4), 8-12.

Charmaz, K. (2003). Grounded theory: Objectivist and constructivist methods. In N. Denzin, \& Y. Lincoln (Eds.), Strategies of qualitative inquiry (pp. 249-291). Thousand Oaks, C.A.: Sage Publications.

Christopher, M. (2005). Logistics and supply chain management: Creating value-adding networks (4th ed.). Essex, ES: Pearson Education Limited.

Cresswell, J. (2012). Qualitative inquiry and research design: Choosing among five approaches. Thousand Oaks, C.A.: Sage Publications.

Crone, M., \& Roper, S. (2001). Local learning from multinational plants: Knowledge transfers in the supply chain. Regional Studies, 35(6), 535-548.

Cusmano, L., Mancusi, M., \& Morrison, A. (2010). Globalisation of production and innovation: How outsourcing is reshaping an advanced manufacturing area. Regional Studies, 44(3), 235-252.

De Simone, L., \& Popoff, F. (2000). Eco-efficiency: The business link to sustainable development. Cambridge, M.A.: MIT Press.

Department of Energy and Climate Change (DECC). (2010). The green deal: A summary of the government's proposals. London, LDN: DECC.

Devine-Wright, P. (2005). Local aspects of UK renewable energy development: Exploring public beliefs and policy implications. Local Environment, 10(1), 57-69.

Emerson, R., Fretz, R., \& Shaw, L. (2011). Writing ethnographic fieldnotes (2nd ed.). Chicago, I.L.: University of Chicago Press.

Fereday, J., \& Cochrane, E. (2006). Demonstrating rigour using thematic analysis: A hybrid approach of inductive and deductive coding and theme development. International Journal of Qualitative Methods, 5(1), 80-92.

Fisher, M. (1997). What is the right supply chain for your product?. Harvard Business Review, 75(2), 105-117.

Flick, U. (2009). An introduction to qualitative research (4th ed.). London, LDN: Sage Publications.

Gall, M., Gall, J., \& Borg, W. (2003). Educational research: An introduction (7th ed.). Massachusetts, M.A.: A \& B Publications.

Haigh, R. (2008). Interviews: A negotiated partnership. In A. Knight, \& L. Ruddock (Eds.), Advanced research methods in the built environment (pp. 111-120). Oxford, O.X.: Blackwell Publishing.

Hamilton, B., \& Summy, M. (2011). Benefits of the smart grid. IEEE Power and Energy Magazine, 9(1), 102-104.

Holstein, J., \& Gubrium, J. (2001). Handbook of interview research: Context and method. Thousand Oaks, C.A.: Sage Publications.

Holweg, M., Disney, S., Holmstrom, J., \& Smaros, J. (2005). Supply chain collaboration: Making sense of the strategy continuum. European Management Journal, 23(2), 170-181.

Howitt, D., \& Cramer, D. (2008). Introduction to research methods in psychology. Essex, ES: Prentice Hall.

Humphrey, J. (2003). Globalisation and supply chain networks: The auto industry in Brazil and India. Global Networks, 3(2), 121-141.

Iacono, J., Brown, A., \& Holtham, C. (2009). Research methods-A case example of participant observation. The Electronic Journal of Business Research Methods, 7(1), 39-46.

Isaksson, R., Johansson, P., \& Fischer, K. (2010). Detecting supply chain innovation potential for sustainable development. Journal of Business Ethics, 97(3), 425-442.

Jackson, J. (1990). "I am a fieldnote”: Fieldnotes as a symbol of professional identity. In R. Sanjek (Ed.), Fieldnotes: The makings of anthropology (pp. 3-33). New York, N.Y.: Cornell University Press.

Kim, S. (1995). Expansion of markets and the geographic distribution of economic activities: The trends in US regional manufacturing structure, 1860-1987. Quarterly Journal of Economics, 110(4), 881-908.

Kumar, R. (2005). Research methodology: A step-by-step for beginners. London, LDN: Sage Publications.

Lam, H., Varbanov, P., \& Klemes, J. (2010). Optimisation of regional energy supply chains utilising renewables: P-graph approach. Computers and Chemical Engineering, 34(5), 782-792.

Langley, P. (1986). Induction and explanation: Complementary models of learning. Behavioural and Brain Sciences, 9(4), 661-662.

Laughlin, P., Davies, P., Dockerill, P., Onyido, T., \& Lansdell, S. (2012). Green deal and ECO: Supply chain and skills development. Retrieved from http://www.shap.uk.com/reports

Lewis, J., \& Wiser, R. (2007). Fostering a renewable energy technology industry: An international comparison of wind industry policy support mechanisms. Energy Policy, 35(3), 1844-1857. 


\section{SUPPLY CHAIN LOCALISATION AS A SOCIAL AND ENVIRONMENTAL BUSINESS VALUE}

Li, X. (2005). Diversification and localization of energy systems for sustainable development and energy security. Energy Policy, 33(17), 2237-2243.

Longo, A., Markandya, A., \& Petrucci, M. (2008). The internalization of externalities in the production of electricity: Willingness to pay for the attributes of a policy for renewable energy. Ecological Economics, 67(1), 140-152.

Melani, C. (2006). Development and the changing dynamics of global production: Global value chains and local clusters in apparel manufacturing. Competition and Change, 10(1), 23-48.

Mulhall, A. (2003). In the field: Notes on observation in qualitative research. Journal of Advanced Nursing, 41(3), $306-313$.

Nassimbeni, G. (2003). Local manufacturing systems and global economy: Are they compatible?: The case of the Italian eyewear district. Journal of Operations Management, 21(2), 151-171.

Omer, A. (2008). Energy, environment and sustainable development. Renewable and Sustainable Energy Reviews, 12(9), 2265-2300.

Perrot, R., \& Filippov, S. (2011). Localisation strategies of firms in wind energy technology development. Journal on Innovation and Sustainability, 2(1), 2-12.

Placet, M., Anderson, R., \& Fowler, K. (2005). Strategies for sustainability. Research Technology Management, 48(5), 32-41.

Pope, C., Ziebland, S., \& Mays, N. (2006). Analysing qualitative data. In C. Pope, \& N. Mays (Eds.), Qualitative research in health care (pp. 63-81). Oxford, O.X.: Blackwell Publishing.

Proverbs, D., \& Gameson, R. (2008). Case study research. In A. Knight, \& L. Ruddock (Eds.), Advanced research methods in the built environment (pp. 99-110). Oxford, O.X.: Blackwell Publishing.

Richard, T. (2010). Challenges in scaling up biofuels infrastructure. Science, 329(5993), 793-796.

Richards, P. (2013). The green deal. London, LDN: House of Commons Library.

Rio, P., \& Burguillo, M. (2009). An empirical analysis of the impact of renewable energy deployment on local sustainability. Renewable and Sustainable Energy Reviews, 13(6-7), 1314-1325.

Ristola, P., \& Mirata, M. (2007). Industrial symbiosis for more sustainable, localised industrial systems. Process in Industrial Ecology, 4(3-4), 184-204.

Saldana, J. (2009). The coding manual for qualitative researchers. Thousand Oaks, C.A.: Sage Publications.

Saunders, M., Thornhill, A., \& Lewis, P. (2006). Research methods for business students (4th ed.). Upper Saddle River, N.J.: Prentice Hall.

Sawin, J. (2006). National policy instruments: Policy lessons for the advancement and diffusion of renewable energy technologies around the world. In D. Assmann, U. Laumanns, \& D. Uh (Eds.), Renewable energy: A global review of technologies, policies and markets (pp. 71-114). London, LDN: Earthscan.

Schmidt, W. (2003). Life cycle costing as part of design for environment: Environmental business cases. The International Journal of Life Cycle Assessment, 8(3), 167-174.

Sheffi, Y. (2001). Supply chain management under the threat of international terrorism. The International Journal of Logistics Management, 12(2), 1-11.

Snow, C., \& Thomas, J. (2007). Field research methods in strategic management: Contributions to theory building and testing. Journal of Management Studies, 31(4), 457-480.

Straka, C. (2002). Local energy policy and smart growth. Local Environment, 7(4), 453-458.

Strauss, A., \& Corbin, J. (1998). Basics of qualitative research: Techniques and procedures for developing grounded theory. Thousand Oaks, C.A.: Sage Publications.

The Economist. (2012). The end of cheap China: What do soaring Chinese wages mean for global manufacturing?. Retrieved from http://www.economist.com/node/21549956

Trochim, W. (1999). Research methods knowledge base (2nd ed.). New York, N.Y.: Cornell University Press.

Tsoutsos, T., Frantzeskaki, N., \& Gekas, V. (2005). Environmental impacts from the solar energy technologies. Energy Policy, 33(3), 289-296.

Walker, G. (1995). Renewable energy and the public. Land Use Policy, 12(1), 49-59.

Wustenhagen, R., \& Bilharz, M. (2006). Green energy market development in Germany: Effective public policy and emerging customer demand. Energy Policy, 34(13), 1681-1696.

Yin, R. (2003). Case study research: Design and methods (3rd ed.). Thousand Oaks, C.A.: Sage Publications.

Yuan, Y. (2001). An inquiry into empirical pragmatics data-gathering methods: Written DCTs, oral DCTs, field notes, and natural conversations. Journal of Pragmatics, 33(2), 271-292. 